Article

\title{
Crop Protection against Botrytis cinerea by Rhizhosphere Biological Control Agent Bacillus velezensis XT1
}

\author{
Laura Toral $^{1, *}$, Miguel Rodríguez ${ }^{2,3} \mathbb{D}$, Victoria Béjar ${ }^{2,3}$ and Inmaculada Sampedro ${ }^{2,3, *(D)}$ \\ 1 Xtrem Biotech S.L., European Business Innovation Center, Avenida de la Innovación, 1, Armilla, \\ 18016 Granada, Spain \\ 2 Department of Microbiology, Faculty of Pharmacy, Campus de Cartuja s/n, 18071 Granada, Spain; \\ miguelrg@correo.ugr.es (M.R.); vbejar@ugr.es (V.B.) \\ 3 Biomedical Research Center (CIBM), Institute of Biotechnology, Avenida del Conocimiento s/n, Armilla, \\ 18100 Granada, Spain \\ * Correspondence: lauratn28@gmail.com (L.T.); isampedro@ugr.es (I.S.)
}

Received: 4 June 2020; Accepted: 1 July 2020; Published: 3 July 2020

\begin{abstract}
This study aims to evaluate the use of Bacillus velezensis strain XT1 as a plant growth-promoting rhizobacterium (PGPR) and biocontrol agent against $B$. cinerea in tomato and strawberry plants. Foliar and radicular applications of strain XT1 increased plant total biomass as compared to the control and B. cinerea-infected plants, with root applications being, on the whole, the most effective mode of treatment. Applications of the bacterium were found to reduce infection parameters such as disease incidence and severity by $50 \%$ and $60 \%$, respectively. We analyzed stress parameters and phytohormone content in order to evaluate the capacity of XT1 to activate the defense system through phytohormonal regulation. Overall, the application of XT1 reduced oxidative damage, while the $\mathrm{H}_{2} \mathrm{O}_{2}$ and malondialdehyde (MDA) content was lower in XT1-treated and $B$. cinerea-infected plants as compared to non-XT1-treated plants. Moreover, treatment with XT1 induced callose deposition, thus boosting the response to pathogenic infection. The results of this study suggest that the signaling and activation pathways involved in defense mechanisms are mediated by jasmonic acid (JA) and ethylene hormones, which are induced by preventive treatment with XT1. The study also highlights the potential of preventive applications of strain XT1 to activate defense mechanisms in strawberry and tomato plants through hormone regulation.
\end{abstract}

Keywords: biocontrol; Botrytis; Bacillus; PGPR; phytohormones; callose; $\mathrm{H}_{2} \mathrm{O}_{2} ;$ MDA; tomato; strawberry

\section{Introduction}

Increasing human populations and demand for food to meet basic requirements are a major challenge for agriculture. In addition to the difficulty of meeting these demands, there is the damage to crops caused by pathogens [1]. Pathogen infections have been estimated to cause a 10-16\% loss in food crops worldwide, which, in economic terms, amounts to 200 million euros annually [2].

Pathogens that cause major economic losses include the necrotrophic fungus Botrytis cinerea. This fungus, which is known to cause gray mold, affects a wide range of host plants and infects over 200 plant species, including important horticultural crops $[3,4]$. The disease process of $B$. cinerea is affected by many pathogenicity determinants, such as host cell wall degradation, cell death and host defense avoidance [5-10]. One of the most important determinants is the production of an exopolysaccharide (EPS) of the $\beta-(1,3)(1,6)$-D-glucan type, which induces salicylic acid (SA) production and antagonizes optimal signaling pathways for plant defenses against $B$. cinerea and the synthesis of enzymes, such as 
copper-zinc superoxide dismutase, that contribute to $\mathrm{H}_{2} \mathrm{O}_{2}$ generation [8-10]. Moreover, its ability to produce conidia enables $B$. cinerea to remain quiescent until conditions are sufficiently favorable to produce the infection [3]. Low host specificity also enables $B$. cinerea to affect a large number of crops worldwide, including tomato and strawberry, both of which are of great economic importance in Spain, where the largest economic losses caused by $B$. cinerea occur during the harvest and storage season [11]. According to the Spanish Ministry of Agriculture, Fisheries and Food (MAPA), in the 2017/2018 period, Spain was one of the largest producers of strawberries in Europe (26\%), with exports of 461.3 million euros, and of tomatoes in the world, with 4.7 million hectares devoted to this crop. In 2016, world tomato production reached 177 million tons according to the Food and Agriculture Organization of the United Nations Statistics Division (FAOAST), with Spain accounting for around 812,571 tons (MAPA) [12,13].

Currently, agricultural management practices are mainly based on the use of chemical pesticides and fertilizers. However, the excessive use of these products has led to the accumulation of residues that are harmful to the environment and humans [14], which has led to the emergence of microbial control agents as an alternative to chemical approaches. These microorganisms, also referred to as plant growth-promoting rhizobacteria (PGPR), which inhibit pathogenic infections, sometimes increase plant growth [15-17]. Strains belonging to the genus Bacillus, such as Bacillus subtilis, B. thuringiensis, B. amyloliquefaciens and B. megaterium, employed in the formulation of PGPR products, are currently used by the agricultural industry to combat and manage pests [18]. In recent decades, the species B. velezensis [19] has become one of the most, if not the most, commonly used PGPR [20]. Some of the strains belonging to this species are capable of producing a wide variety of metabolites, such as siderophores [21], enzymes [18], volatile organic compounds (VOC) and lipopeptides [22-28], which contribute to both their biofertilizing activity and biocontrol capacity through direct competition, by activating induced systemic resistance (ISR) and by modifying the host-plant microbiome [29].

One of the biological control systems developed by plants, which play an important role in protecting against pathogenic infections, is induced systemic resistance (ISR), which activates different signal transduction pathways [30]. A large number of non-pathogenic rhizobacterial species have the ability to trigger ISR by producing elicitors which are perceived by plants and reinforce their defensive systems [31-33]. ISR-activated defense responses include the accumulation of callose deposits on cell walls [34,35] and the production of hydrogen peroxide $\left(\mathrm{H}_{2} \mathrm{O}_{2}\right)[36,37]$. The phytohormones salicylic acid (SA), jasmonic acid (JA), abscisic acid (ABA) and ethylene (ET) play a fundamental role in the initiation and regulation of these defense mechanisms [38-40]. The coordination of defenses against biotrophic pathogens is generally mediated by the action of SA, while the JA/ET tandem is associated with protection against necrotrophic pathogens such as Botrytis [41]. The regulation of both SA and JA/ET systems has been reported, in some cases, to have an antagonistic effect, with the activation of SA increasing susceptibility to necrotrophic pathogens [8].

With the aim of marketing a biological product with plant growth promotion (PGP) potential and antifungal activity against $B$. cinerea, this study evaluated the biocontrol activity of $B$. velezensis strain XT1 CECT 8661 against the necrotrophic fungus $B$. cinerea in tomato and strawberry plants. To that end, we analyzed the activation of defense mechanisms in tomato and strawberry plants, as well as the induced resistance mechanisms involved in these responses.

\section{Materials and Methods}

\subsection{Bacterial and Fungal Strains, Media and Culture Conditions}

The patented Bacillus velezensis strain XT1 (CECT $8861^{\mathrm{T}}$ ) under license to Xtrem Biotech S.L. (ES2639375B1) was used in this study [19]. This strain was isolated from the Juncus effusus rhizosphere in a saline habitat located in Málaga (Spain). The fungal pathogen Botrytis cinerea, which was isolated from a Syrah vineyard, was kindly provided by the University of Zaragoza (Spain). Bacterial strains were cultured in a nutrient broth $(0.1 \%(w / v)$ meat extract, $0.2 \%(w / v)$ yeast extract, $0.5 \%(w / v)$ peptone, 
$0.5 \%(w / v) \mathrm{NaCl})$ at $28^{\circ} \mathrm{C}$ and in a rotary shaker at $120 \mathrm{rpm}$ for $48 \mathrm{~h}$ unless stated otherwise. B. cinerea was grown in potato dextrose medium (Difco ${ }^{\circledR}$ ) at $21^{\circ} \mathrm{C}$ for 15 days.

\subsection{In Vivo Evaluation of the Antifungal Activity of XT1 Strain against B. cinerea}

In order to determine the efficiency of different modes of treatment, foliar spraying and root irrigation were used to apply strain XT1 to tomato (Solanum lycopersicum L. cv. Mina) and strawberry (Fragaria ananassa cv. San Andreas) plants. Both types of plants were cultured in $1 \mathrm{~L}$ pots filled with sterile potting soil (Compo Sana universal substrate, Compo, Münster, Germany) and placed randomly in a greenhouse at $25^{\circ} \mathrm{C} / 20{ }^{\circ} \mathrm{C}$ (day/night), relative humidity 70-90\%, a long-day photoperiod (16:8 $\mathrm{h}$ light:dark) and a luminosity of $250 \mu \mathrm{S} \mathrm{cm}{ }^{-2} \mathrm{~s}^{-1}$. Four conditions were assayed for each type of application: sterile distilled water as non-inoculated treatment $(C) ; B$. cinerea-infected non-treated plants (Bc); XT1-treated plants (XT1); as well as $B$. cinerea + strain XT1 $(\mathrm{XT} 1+\mathrm{Bc})$. The plants were divided into three separate replicates per treatment, each with 12 plants. Briefly, 7 days after sowing, each plant of the treatments XT1 and XT1-Bc was firstly foliar sprayed or root irrigated, respectively, with $150 \mathrm{~mL}$ of a $1 / 5$ and $1 / 20$ diluted five-day-old culture of strain XT1 $\left(10^{8} \mathrm{CFU} \mathrm{mL}^{-1}\right)$ in sterile distilled water in PLOM medium (developed by Xtrem Biotech S.L., under industrial secret). Seven days later, Bc and XT1-Bc plants were foliar sprayed and root irrigated with a conidial suspension of B. cinerea $\left(10^{6}\right.$ conidia $\left.\mathrm{mL}^{-1}\right)$. Two days later, a $1 / 5$ and $1 / 40$ dilution of a five-day-old culture of strain XT1 was applied, in XT1 and XT1-Bc treatments, using foliar spraying or root irrigation, respectively. The first inoculation was carried out to study the improvement of the resistance of the plant to invasion by the pathogen, and the second as a mechanism of direct antifungal activity against B. cinerea.

Seven days later, the plants were harvested and aerial and radicular parts were weighed for each treatment. Infection symptoms were examined and disease incidence (\% of plant infected) and severity in terms of chlorosis, withering, necrosis and defoliation was determined using a $0-4$ severity scale: 0 , healthy plant; 1, damage 1-33\%; 2, damage 34-66\%; 3, damage 67-99\% and 4, dead plant [42]. For each experiment, a total of ten plants were used per treatment.

Physiological parameters were determined for each treatment. A pool of foliar samples belonging to all plants were ground with liquid nitrogen and from the mixture, three technical replicates were performed. Hydrogen peroxide content was measured at $415 \mathrm{~nm}$ following the extraction of foliar samples with cold acetone [43]. Membrane lipid peroxidation was measured by malondialdehyde (MDA) quantification [44]. Callose deposition in fresh leaves was analyzed by fluorescence microscopy $(380 \mathrm{~nm})$ following ethanol discoloration and methylene blue staining [45]. Finally, the content of the phythormones ethylene, cytokinin, auxin, gibberellin, abcisic acid (ABA), jasmonic acid (JA) and salicylic acid (SA) in plant tissue was determined by ultrahigh-performance liquid chromatography-mass spectrometry (UPLC-MS) according to the protocol described by Stevens and Berry (1988) [46].

\subsection{Protection by XT1 against Damage Caused by B. cinerea in Tomato and Strawberry Leaves}

From each treatment $(\mathrm{C}, \mathrm{XT1}, \mathrm{Bc}$ or $\mathrm{XT1}+\mathrm{Bc})$, tomato and strawberry leaves were placed on square petri dishes $(120 \times 120 \mathrm{~mm})$ containing a layer of sterile glass beads $(\varnothing 4 \mathrm{~mm})$ and $25 \mathrm{~mL}$ of sterile distilled water to maintain a humidity of $80 \%$. Three incisions per leaf were made using a scalpel, and each wound was inoculated with $15 \mu \mathrm{L}$ of $B$. cinerea $\left(10^{6}\right.$ conidia $\left.\mathrm{mL}^{-1}\right)$. The petri dishes were sealed with parafilm and incubated at $21{ }^{\circ} \mathrm{C}$ for 3 days. Signs of necrosis (brown spots) and chlorosis were then evaluated. Three technical replicates with two leaves in each one were performed for each treatment.

\subsection{Statistical Analysis}

Variance analysis was performed using ANOVA and the Kruskal-Wallis test $(p \leq 0.05)$. Significant differences between treatments were analyzed with the aid of Fisher's least significant difference (LSD) test $(p \leq 0.05)$. Significance was expressed as: ${ }^{*}, p \leq 0.05 ;{ }^{* *}, p \leq 0.01 ;{ }^{* *}, p \leq 0.001$; NS, non-significant. 
All analyses were carried out using Statgraphics Centurion XVI (StatPoint Technologies, Inc., Warrenton, VA, USA) and GraphPad Prism 7.04 (GraphPad Software, San Diego, CA, USA) software.

\section{Results}

Tomato and strawberry experiments under greenhouse conditions were carried out to evaluate the effectiveness of the foliar spraying or root irrigation of $B$. velezensis strain XT1 in promoting growth and in suppressing gray mold disease caused by $B$. cinerea.

\subsection{Growth Parameters}

The plant growth promotion capacity of foliar sprayed and root irrigated strain XT1 was analyzed in tomato and strawberry plants by determining aerial and radicular weight. In tomato plants, we observed plant growth promotion activity following radicular applications of XT1, as indicated by a $20 \%$ increase in radicular weight $(p \leq 0.001)$ with respect to the non-inoculated plant $(C)$. This increase was higher $(34 \%, p \leq 0.001)$ in XT1-treated and B. cinerea-infected plants $(\mathrm{XT} 1+\mathrm{Bc})$ as compared to B. cinerea-infected plants (Bc) (Figure 1). Nevertheless, although the appearance of infected plants (Bc) differed considerably from that of XT1-treated infected plants $(\mathrm{XT1}+\mathrm{Bc})$, no significant differences in foliar weight were found following treatment. Foliar applications of strain XT1 showed no significant differences in foliar or radicular weight between non-inoculated plants (C) and XT1-treated plants (XT1) (Figure 1).
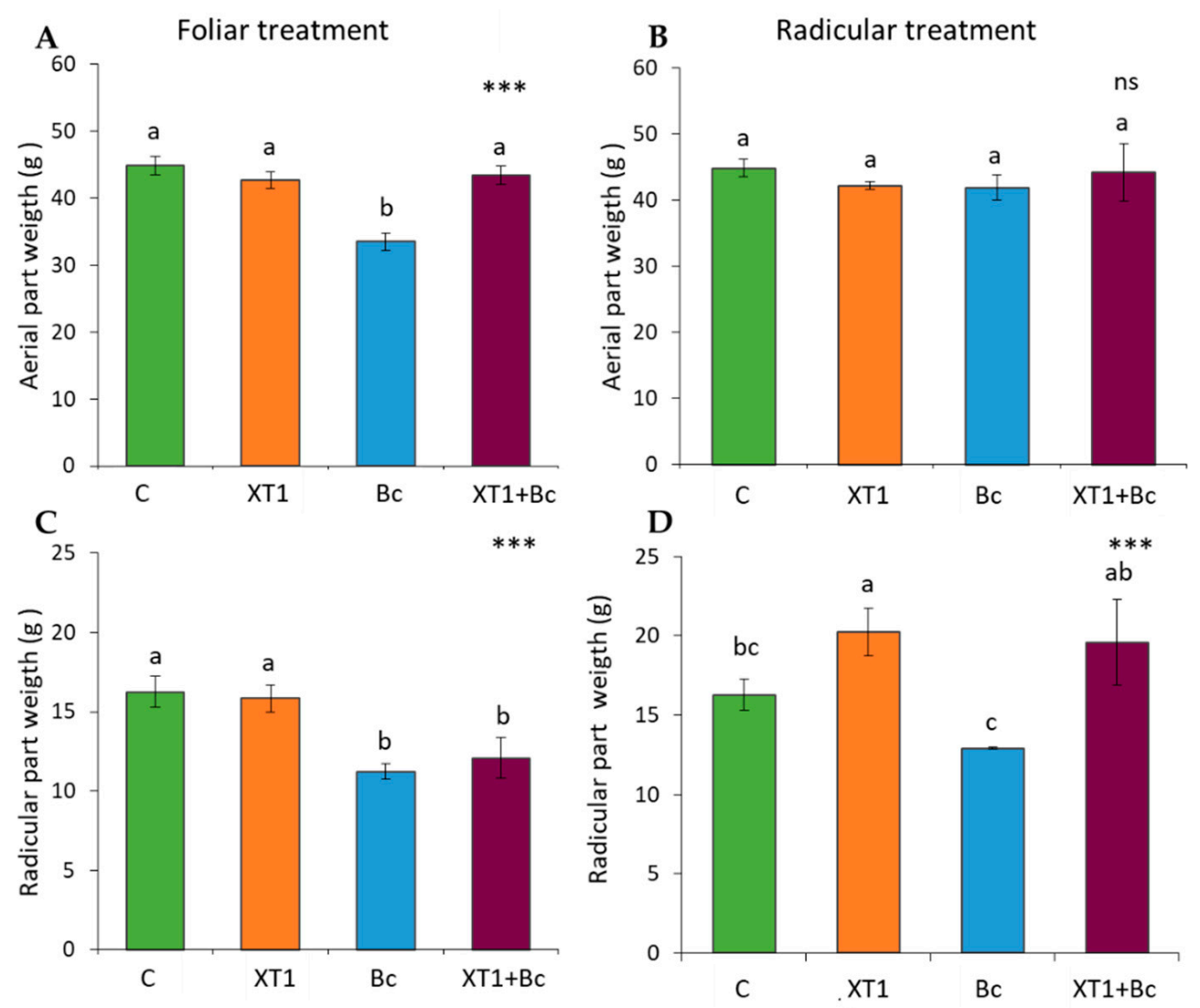

Figure 1. Effect of XT1 foliar (A,C) and radicular (B,D) applications on tomato plants. C: non-inoculated control plants; XT1: XT1-treated plants; Bc: B. cinerea-infected non-treated plants; XT1+Bc: XT1-treated $B$. cinerea-infected plants. Letters above the main bars represent statistical differences according to the Fisher test ${ }^{* * *}(p \leq 0.001)$, ns (no significance). Significant differences between treatments are indicated by different letters $(a, b, c)$. 
Similar results were observed for both non-infected and infected strawberry plants following radicular applications of XT1, with root biomass increasing by $30 \%$ with respect to their respective non-inoculated controls (C) and B. cinerea-infected non-treated plants (Bc) (Figure 2D). On the other hand, we also observed plant growth promotion activity following radicular (Figure 2B) and foliar applications (Figure 2A) of XT1 in the aerial parts, the weight of which increased by $20 \%(p \leq 0.001)$, particularly in XT1-treated plants as compared to non-inoculated plants (C); both parameters were also significantly higher in XT1-treated $B$. cinerea-infected plants $(\mathrm{XT1}+\mathrm{Bc})$ in relation to the $B$. cinerea-infected control and non-treated plants $(\mathrm{Bc})$. No increase in radicular weight was observed following foliar treatment (Figure 2C).
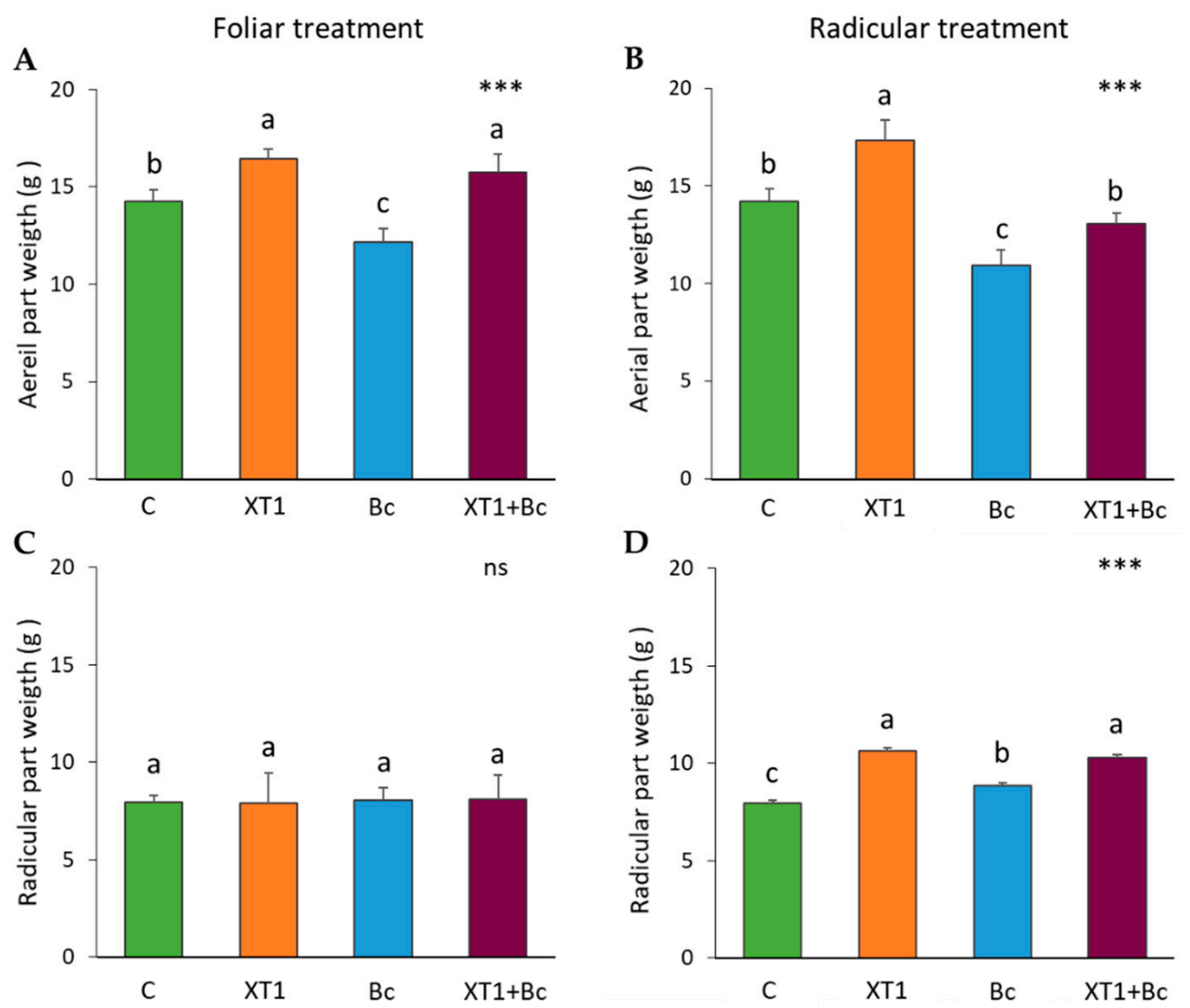

Figure 2. Plant growth promotion (PGP) effect of XT1 foliar $(\mathbf{A}, \mathbf{C})$ and radicular $(\mathbf{B}, \mathbf{D})$ applications on strawberry plants. C: non-inoculated control plants; XT1: XT1-treated plants; Bc: B. cinerea-infected non-treated plants; XT1+Bc: XT1-treated B. cinerea-infected plants. Letters above the main bars represent statistical differences according to the Fisher test ${ }^{* * *}(p \leq 0.001)$, ns (no significance). Significant differences between treatments are indicated by different letters $(a, b, c)$.

\subsection{Biocontrol Effect of Strain XT1 on Tomato and Strawberry Plants}

The progression of gray mold disease caused by $B$. cinerea in infected tomato and strawberry plants was recorded after inoculation with the pathogen by determining disease incidence (DI) and the severity index for each treatment. In both tomato and strawberry crops, DI in the B. cinerea-infected plants (Bc) was over 70\%. Moreover, the severity index exceeded $32 \%$ in all cases (Figure 3). Foliar and radicular applications of XT1 were found to reduce the severity of fungal pathogen infection. Specifically, both plants showed a sharp reduction of $50 \%$ in DI (data not shown) and of $60 \%$ in severity in infected XT1-treated B. cinerea-infected plants $(\mathrm{XT1}+\mathrm{Bc})$ with respect to infected non-treated plants (Bc) (Figure 3). 

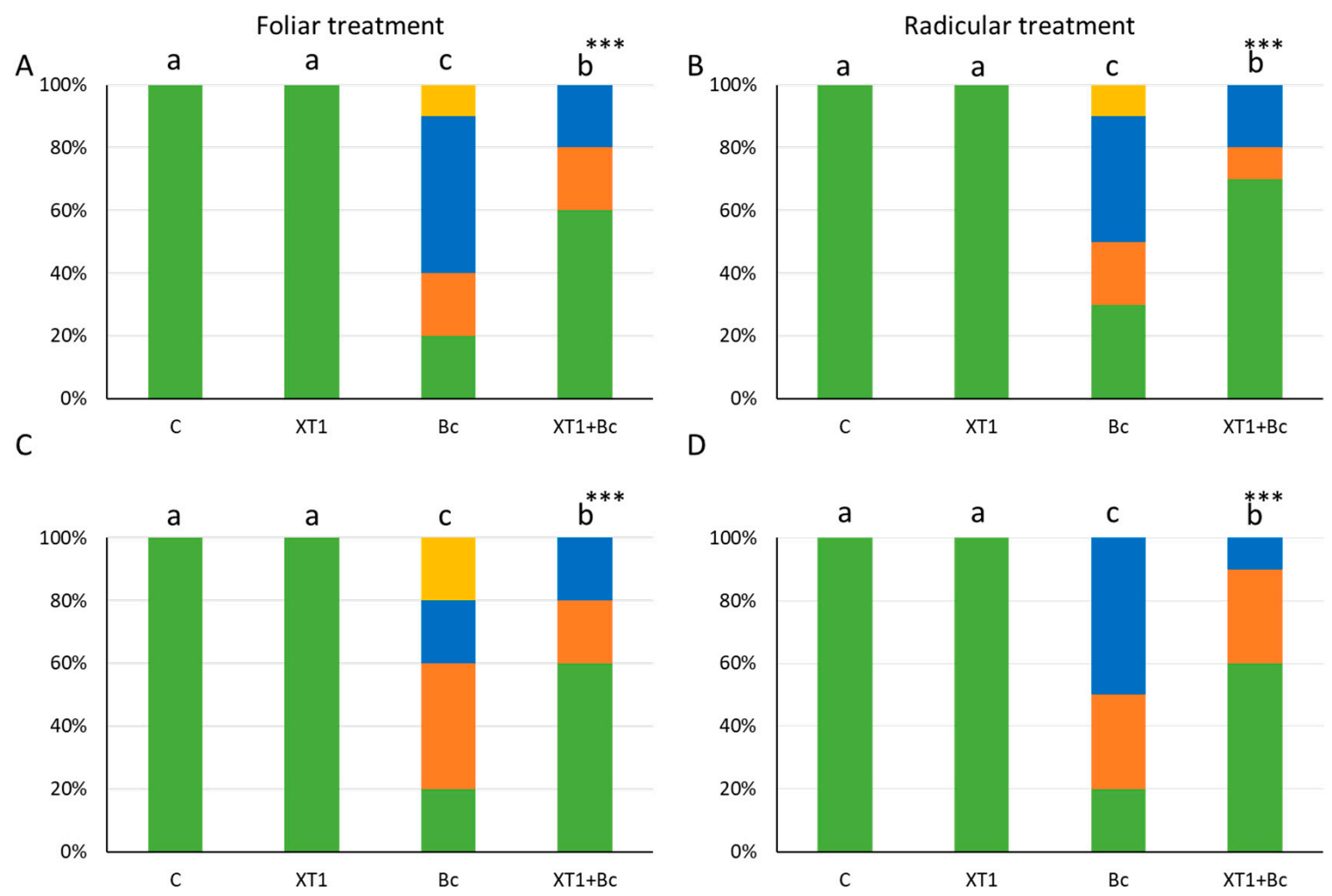

Figure 3. Severity of damage (\%) caused by B. cinerea in tomato (A,B) and strawberry $(\mathbf{C}, \mathbf{D})$ plants after foliar and radicular treatment with XT1. C: non-inoculated control plants; XT1: XT1-treated plants; Bc: B. cinerea-infected non-treated plants; XT1+Bc: XT1-treated B. cinerea-infected plants. Statistical differences according to the Kruskal-Wallis test ${ }^{* * *}(p \leq 0.001)$. Significant differences between treatments are indicated by different letters $(a, b, c)$.

\subsection{Effect of XT1 Treatment on Oxidative Status in Tomato and Strawberry Plants}

In this study, membrane damage caused by oxidative stress was estimated by analyzing the superoxide anion $\mathrm{H}_{2} \mathrm{O}_{2}$, as well as malondialdehyde (MDA) levels. The results for hydrogen peroxide in tomato plants revealed significant differences between radicular treatment with XT1-treated and non-inoculated plants (C) (Figure 4B). However, this treatment only produced a slight decrease in XT1-treated B. cinerea-infected tomato plants $(\mathrm{XT1}+\mathrm{Bc})$ as compared to infected non-treated plants $(\mathrm{Bc})$ (Figure 4B). No differences were found in foliar-treated tomato plants (Figure 4A).

Unlike tomato plants, the foliar treatment of strawberry plants was responsible for differences in $\mathrm{H}_{2} \mathrm{O}_{2}(p \leq 0.01)$ levels between non-inoculated (C) and XT1-treated plants (XT1) (Figure 4C). Likewise, the foliar treatment of strawberry plants reduced $\mathrm{H}_{2} \mathrm{O}_{2}$ levels $(p \leq 0.01)$ in XT1-treated B. cinerea-infected plants $(\mathrm{X} \mathrm{t} 1+\mathrm{Bc})$ as compared to $B$. cinerea-infected non-treated plants $(\mathrm{Bc})$ (Figure $4 \mathrm{C})$, while radicular treatment produced only a slight reduction in hydrogen peroxide between these two types of treatments (Figure 4D).

Cell damage caused by lipid peroxidation in leaves was estimated by measuring the levels of MDA. The XT1-treated plants (XT1) showed low MDA levels in root-treated tomato (Figure 5B) and foliar-treated strawberry plants (Figure $5 \mathrm{C}$ ) as compared to non-inoculated plants (C). The results for both plants and both foliar and radicular applications of XT1 indicate a reduction in MDA levels in XT1-treated $B$. cinerea-infected plants $(\mathrm{XT1}+\mathrm{Bc})$ with respect to infected non-treated plants $(\mathrm{Bc})$ $(p \leq 0.001)$ (Figure 5). 

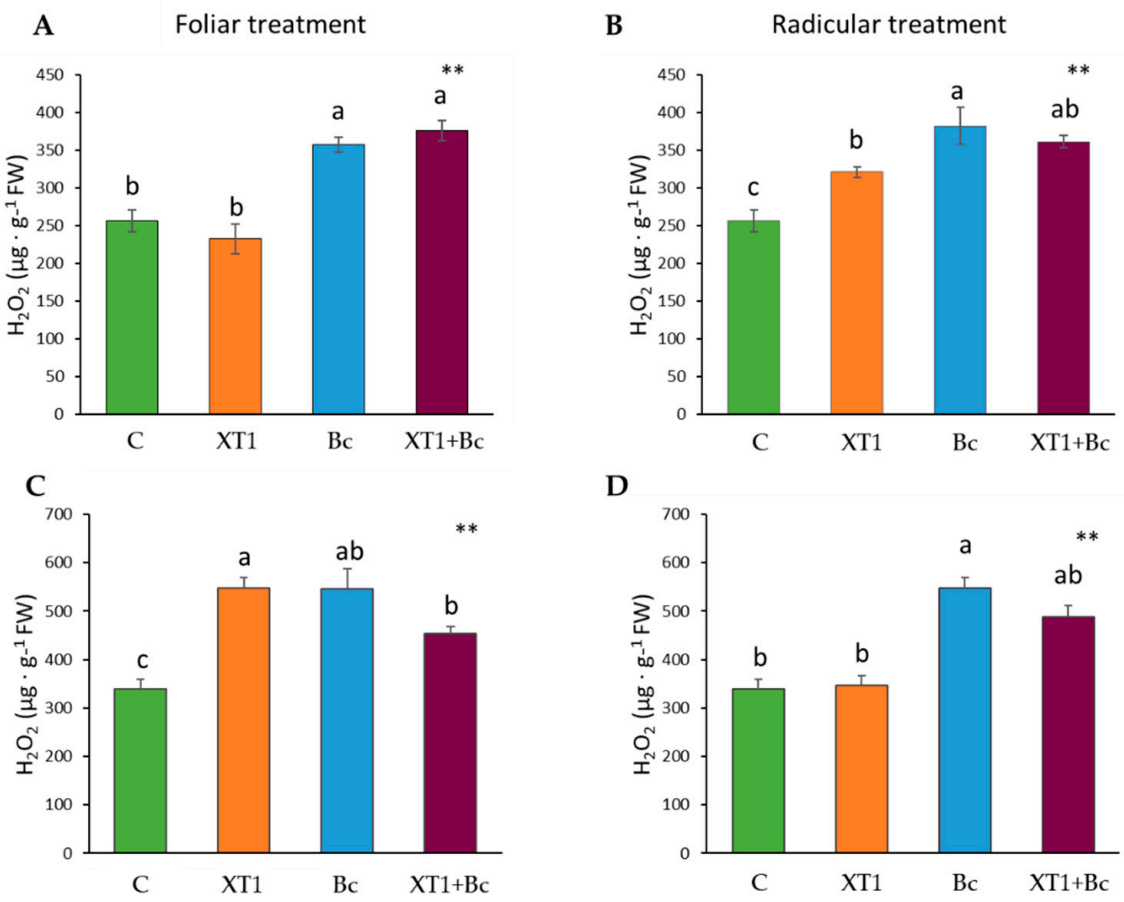

Figure 4. $\mathrm{H}_{2} \mathrm{O}_{2}$ content in tomato $(\mathbf{A}, \mathbf{B})$ and strawberry $(\mathbf{C}, \mathbf{D})$ plants after foliar and radicular XT1 treatment. C: non-inoculated control plants; XT1: XT1-treated plants; Bc: B. cinerea-infected non-treated plants; XT1+Bc: XT1-treated B. cinerea-infected plants. Letters above the main bars represent statistical differences according to the Fisher test ${ }^{* *}(p \leq 0.01)$. Significant differences between treatments are indicated by different letters $(\mathrm{a}, \mathrm{b}, \mathrm{c})$.
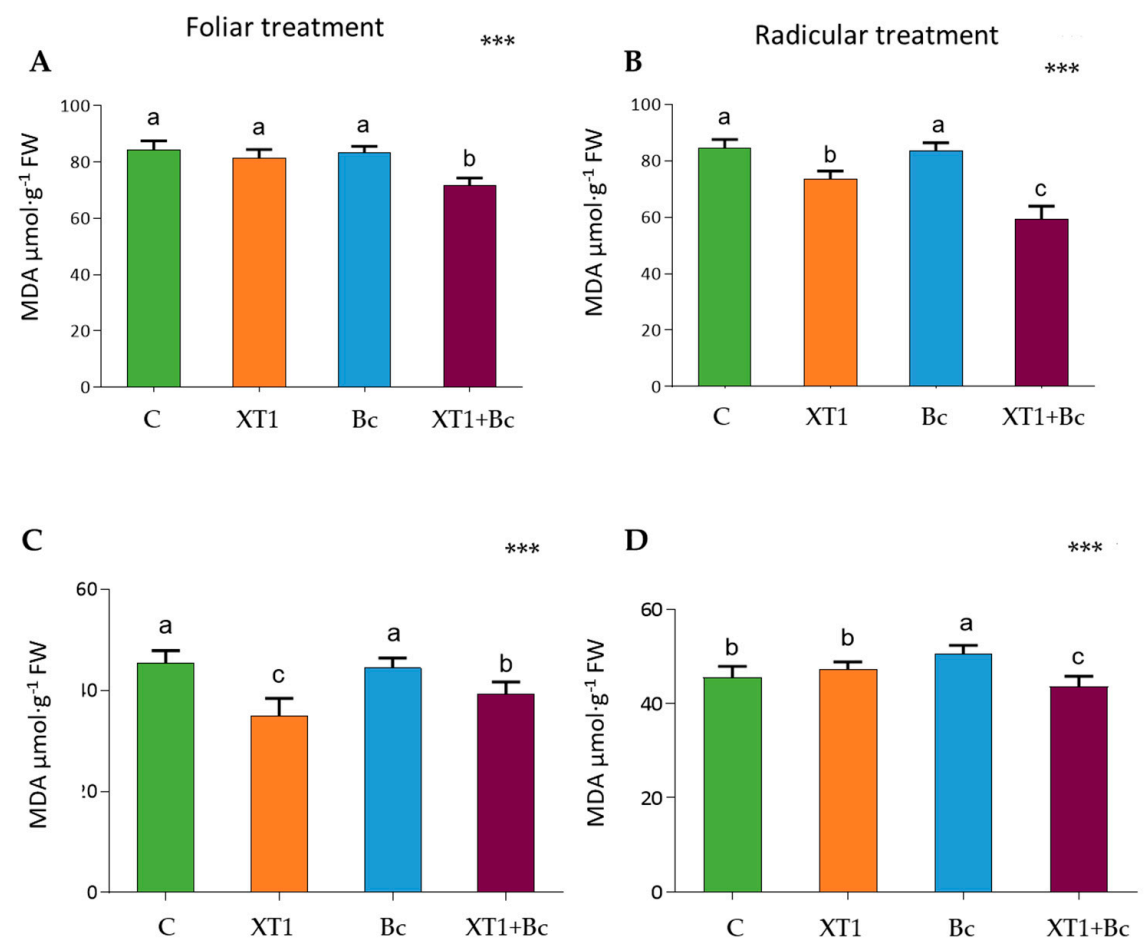

Figure 5. Malondialdehyde (MDA) content in tomato (A,B) and strawberry (C,D) plants after foliar and radicular XT1 treatments. C: non-inoculated control plants; XT1: XT1-treated plants; Bc: B. cinerea-infected non-treated plants; XT1+Bc: XT1-treated B. cinerea-infected plants. Letters above the main bars represent statistical differences according to the Fisher test ${ }^{* *}(p \leq 0.001)$. Significant differences between treatments are indicated by different letters $(a, b, c)$. 


\subsection{Callose Deposition in Tomato and Strawberry Plants}

Preventive foliar and radicular applications of strain XT1 in B. cinerea-infected $(\mathrm{XT} 1+\mathrm{Bc})$ tomato and strawberry plants increased callose deposits considerably in leaves as compared to infected non-treated plants $(\mathrm{Bc})$. This increase was also pronounced in XT1-treated non- $B$. cinerea-infected plants (XT1) compared to uninoculated plants (C) (Figure 6).

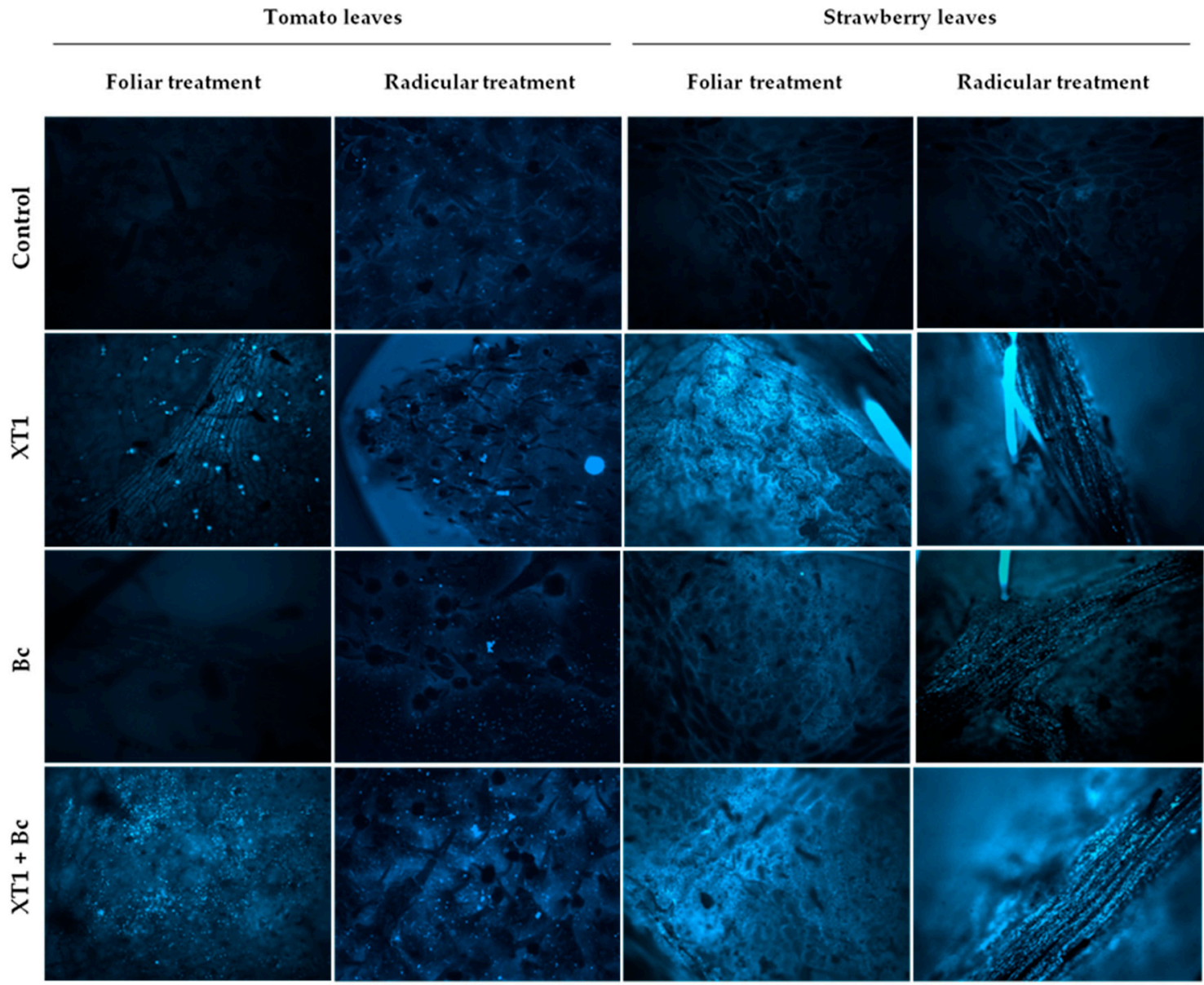

Figure 6. Callose deposition in tomato and strawberry plants after XT1 treatment and $B$. cinerea infection. Control: non-inoculated plants; XT1: XT1-treated plants; Bc: B. cinerea-infected non-treated plants; XT1+Bc: XT1-treated B. cinerea-infected plants. Optical parameters: magnification 20×; gain 2.1; exhibition 1.06; gamma 3.06; color 471 .

\subsection{Evaluation of XT1-Induced Resistance against B. cinerea in Tomato and Strawberry Leaves}

The effectiveness of strain XT1 in increasing tomato and strawberry resistance against $B$. cinerea was tested. Detached leaves of non-inoculated and XT1 root-inoculated plants were infected with the pathogen (Figure 7). Leaves belonging to XT1-treated plants (XT1) and XT1-treated B. cinerea-infected plants $(\mathrm{XT} 1+\mathrm{Bc})$ showed minor symptoms of damage (brown spots and necrosis) of the infected area as compared to those from non-inoculated $(\mathrm{C})$ and B. cinerea-infected $(\mathrm{Bc})$ plants. Specifically, the damage caused around the infection zone decreased by $85 \%$ in tomato and by $75 \%$ in strawberry leaves from the $\mathrm{XT} 1+\mathrm{Bc}$ treatments compared to the Bc treatment.

\subsection{Effect of Treatment with XT1 on Phytohormone Content}

Radicular applications of XT1, Bc and XT1+Bc increased the levels of the phytohormones ethylene, JA and SA as compared to non-inoculated plants (C) (Figure 8). As shown in the heat map, the application of strain XT1 did not affect the content of hormones gibberellin A4 (GA4), ABA and the 
cytokinin isopentenyl-adenine. On the other hand, the preventive application of XT1 (XT1) resulted in three-fold higher JA levels as compared to non-inoculated plants (C). Under the conditions described above, the level of SA in tomato and strawberry plants was observed to increase by approximately $20 \%$ and $35 \%$, respectively. Although ethylene content rose slightly, a significant increase in SA and JA levels was observed in $B$. cinerea- infected XT1-treated strawberry plants $(X T 1+B c)$ with respect to infected non-treated strawberry plants $(\mathrm{Bc})$. In the case of tomato plants, the JA values were the only ones increased by the preventive use of the strain XT1 (XT1+Bc) compared to infected plants (Bc). On the other hand, radicular applications of XT1 induced the production of the gibberellins GA1 and GA3 in tomato plants, but produced only GA1 in the case of strawberry plants. Finally, according to the results, the treatment with the strain XT1 (XT1) reduced the content of auxins compared with uninoculated tomato and strawberry plants $(\mathrm{C})$.
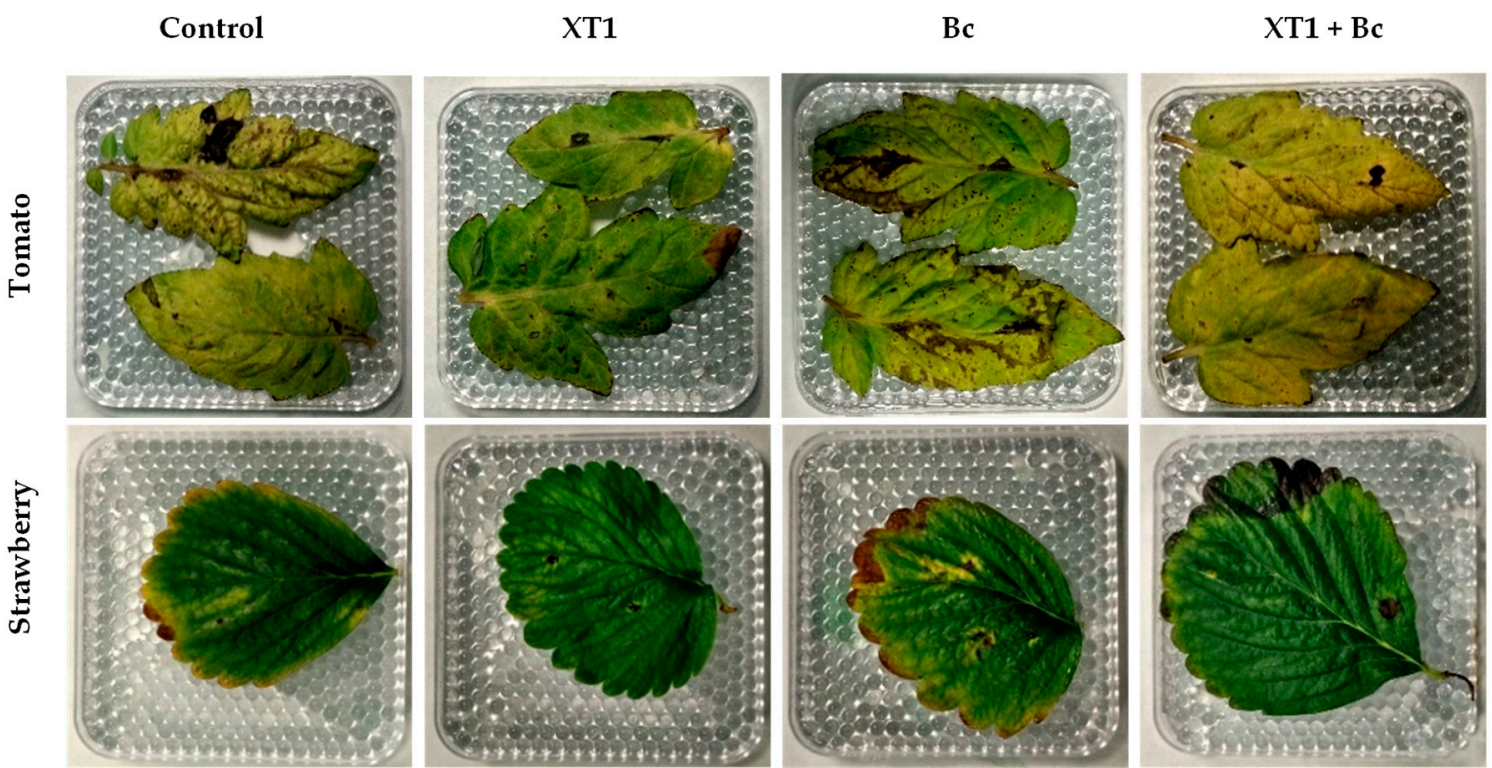

Figure 7. Effect of inoculation with strain XT1 on leaves from B. cinerea-infected strawberry and tomato plants. Leaves from negative control (C), XT1-treated (XT1), B. cinerea-infected non-treated (Bc) and $\mathrm{XT1}$-treated B. cinerea-infected $(\mathrm{XT} 1+\mathrm{Bc})$ tomato and strawberry plants.

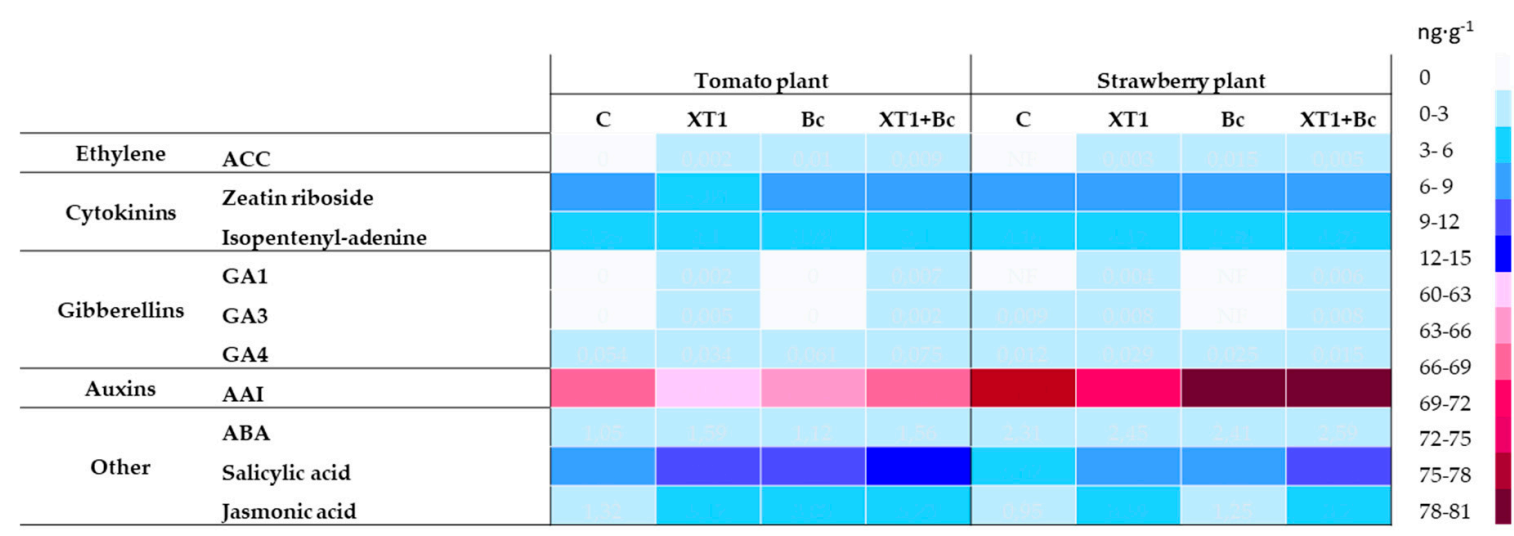

Figure 8. Effect of XT1 inoculation and B. cinerea infection on phytohormone content in tomato and strawberry plants. C: non-inoculated control plants; XT1: XT1-treated plants; Bc: B. cinerea-infected non-treated plants; XT1+Bc: XT1-treated B. cinerea-infected plants.

\section{Discussion}

Although treatments based on extensive pesticide use are usually carried out to control gray mold caused by $B$. cinerea, many restrictions are imposed on these products within the framework of EU 
pesticide regulation No 1107/2009 [47,48]. In addition, pesticide use involves the production of waste and contaminants from groundwater that increase human health and environmental risks $[6,49,50]$. Thus, one of the major challenges facing sustainable agriculture is the development of alternatives that respect the environment and safeguard human health. Over the past decade, bacterial strains have been increasingly used as biological control agents given their broad spectrum of action against phytopathogens, as well as their eco-friendly properties.

B. velezensis strain XT1 was isolated in 2001 from the rhizosphere of a Juncus effusus (soft rush), which was grown in a saline soil (histosol; Soil Survey Staff, 2010) adjacent to the Capacete lagoon (Málaga, Spain) and patented by the University of Granada under Bucharest Convention guidelines, was deposited in the Spanish Type Culture Collection as CECT 8661 and licensed to Xtrem Biotech S.L. [51]. In this study, we evaluated the potential use of XT1 as a plant growth promoter and biocontrol agent against $B$. cinerea. The effect of the fungus on tomatoes and strawberries, two economically important crops, was evaluated [11,52-54].

The plant growth-promoting capacity of strains belonging to the genus Bacillus has been widely demonstrated [20,55-59], and B. velezensis strain BAC03 has been found to enhance the growth of nine different plant types and to increase biomass [58]. On the other hand, B. velezensis strain CBMB205 increases the root length of tomato, red pepper and canola plants by $38.3,4.2$ and $22.4 \%$, respectively [60]. Previous studies have also demonstrated that $B$. velezensis strain XT1 enhances the growth capacity of several crops [61]. However, a study by Palencia et al. (2015) [62] on the effect of treatment with B. velezensis strain IT45 on strawberry plants, found that the growth promotion was low in comparison with the uninoculated plants.

Growth promotion capacity has, in some cases, been linked to the mode of application used. Salvatierra-Martínez et al. (2018) [13] demonstrated that only radicular applications of B. subtilis strains BBC023 and BBC047 are capable of enhancing biomass production. Similarly, Esitken et al. (2010) [63] found that not all PGPR strains of the genus Bacillus act in a similar fashion in strawberry plants and that crop yields, in some cases, increase following root applications of Bacillus strain M3 and, in other cases, after foliar applications of Bacillus OSU142.

Our results demonstrate that radicular applications of strain XT1 (XT1) induce higher total biomass levels in strawberry plants and a slight increase in tomato plants as compared to uninoculated plants (C). We also show that foliar treatment with XT1 in strawberry plants only significantly affects the aerial biomass. All these results show that growth-promoting activity is closely linked to the mode of application of B. velezensis.

With regard to fungal mycelium growth inhibition, several strains of $B$. velezensis have been reported to suppress the in vitro growth of fungal phytopathogens such as the biotrophic/saprotrophic Trichoderma, the hemibiotrophic Fusarium and the necrotrophics Alternaria and Monilinia [64-66]. In two previous studies, we demonstrated that strain XT1 inhibits the mycelium growth of Alternaria alternata, Fusarium oxysporum, Magnaporthe oryzae, Sclerotinia sclerotiorum and Thanatephorus cucumeris by over $40 \%$. Antagonistic activity against the pathogens Monilinia fructicola [61] and B. cinerea (60\%) reached maximum levels of $>80 \%$ and $60 \%$, respectively, mainly due to the large amount of lipopeptides produced (10 g/L) [67]. Many studies of olive, tomato, corn, peanut, pepper, maize and rice crop yields have also described the biocontrol activity of $B$. velezensis strains against phytopathogens such as Verticillium dahliae, Fusarium graminerarum, Sclerotium rolfsii, Phytophthora and B. cinerea [68-74]. Our results are in line with the findings of Lee et al. (2006) [75] who investigated the effect of radicular applications of $B$. subtilis WXCDD105 on B. cinerea in tomato plants. However, studies by Salvatierra-Martínez et al. (2018) [13] of radicular applications of B. subtilis strains detected low antifungal activity. Little is known about the antifungal impact of root treatments on $B$. cinerea biocontrol activity in strawberry plants. Current research mainly focuses on foliar applications of other Bacillus strains, such B. amyloliquefaciens FZB42 (formerly B. velezensis), B. amyloliquefaciens, B. subtilis, B. licheniformis and B. megaterium $[53,76,77]$. In this study, in vivo experiments with tomato and 
strawberry crops confirmed the reduction in gray mold incidence and the severity of damage (around $50-60 \%$ ) caused by $B$. cinerea in tomato and strawberry crops following applications of strain XT1.

Previous studies have highlighted the crucial role played by surfactins and 2-3 butanediol as antimicrobial agents and as compounds which activate induced systemic resistance (ISR) and promote plant growth [32,78-81]. Strain XT1 produces these compounds [67] and other metabolites [61] which facilitate its antifungal and PGPR activities. The successful antifungal results following radicular applications of strain XT1, as well as its PGP capacity, can be ascribed, not only to the anti-pathogenic action of metabolites, but also to the application method used, which plays an important role in controlling the pathogen $B$. cinerea.

The mechanisms involved in the rapid production of plant cellular defense responses to pathogens include rapid $\mathrm{H}_{2} \mathrm{O}_{2}$ accumulation [82], which is known to be a hallmark event induced by ISR-triggering bacteria [35,83]. In order to restrict pathogenic infection, $\mathrm{H}_{2} \mathrm{O}_{2}$ accumulation is involved in mechanisms such as plant cell wall modifications, signaling stress, systemic acquired resistance (SAR) system and hypersensitive response (HR) activation, defensive gene induction, phytoalexin synthesis and ultimately cell death initiation [84-87]. We observed an increase in hydrogen peroxide following treatment with XT1 (XT1) in some cases, as well as slight a decrease in this compound in infected and treated plants $(\mathrm{XT1}+\mathrm{Bc})$. Previous studies have reported that the early activation of defense systems, and thus $\mathrm{H}_{2} \mathrm{O}_{2}$ accumulation, boosts resistance against $B$. cinerea in tomato and strawberry plants [84,87-89]. Although hydrogen peroxide accumulation has been widely shown to contribute to defense against pathogens, different studies have shown that virulence factors in necrotrophic organisms such as $B$. cinerea play a very important role in the induction of unregulated reactive oxygen species (ROS) production [86,87], which explains the high levels of ROS in B. cinerea-infected plants observed in this study. Nie et al. (2017) [90] found that after infection with $B$. cinerea, plants pretreated with $B$. cereus AR156 accumulated higher $\mathrm{H}_{2} \mathrm{O}_{2}$ levels than infected non-treated plants, which enhanced and accelerated the defense response. However, we observed different results. Excessive ROS accumulation can be harmful to plants, leading to oxidative stress damage to their deoxyribonucleic (DNA) acids, proteins, chlorophylls and membrane functions. Thus, $\mathrm{H}_{2} \mathrm{O}_{2}$ levels [91] need to be optimally balanced to prevent excessive ROS accumulation in B. cinerea-infected XT1-treated plants.

Apart from hydrogen peroxide, malondialdehyde (MDA) is another parameter associated with plant oxidation status. MDA determines the lipid peroxidation produced by ROS, which directly affects the cellular lipid membrane, leading to oxidative degradation and cell lysis [92,93]. Preventive foliar and root applications of $B$. velezensis strain XT1 reduce the MDA content in $B$. cinerea-infected tomato and strawberry plants $(\mathrm{XT} 1+\mathrm{Bc})$. Although similar results have been obtained using different Bacillus strains and crops [92,94], to our knowledge, no previous studies demonstrate the ability of B. velezensis to reduce MDA levels in plants affected by B. cinerea, a mechanism which might explain the in vivo antifungal activity of strain XT1.

As with hydrogen peroxide, callose accumulation is regarded as a defense response induced by ISR-triggering bacteria $[35,83]$. Preventive foliar and radicular applications of strain XT1 in B. cinerea-infected tomato and strawberry plants $(\mathrm{XT} 1+\mathrm{Bc})$ resulted in a considerable increase in callose deposits. Cell wall reinforcement caused by increased callose deposition has been widely demonstrated to be an important defense against the development of $B$. cinerea $[86,88,90]$. However, little is known about the induction of callose deposition by other Bacillus species in response to $B$. cinerea infection in tomato and strawberry plants. In order to test the effectiveness of $B$. velezensis XT1 in increasing tomato resistance to $B$. cinerea in tomato and strawberry plants, infection bioassays were carried out on leaves. Remarkably, inoculation with XT1 resulted in a significant reduction in disease symptoms in both crops.

The phytohormones salicylic acid (SA), jasmonic acid (JA), abscisic acid (ABA) and ethylene (ET) play a fundamental role in the initiation and regulation of the plant defense mechanisms mentioned above [38-40]. More specifically, plant defense responses to $B$. cinerea are coordinated by the interplay 
between JA- and SA-regulated signaling pathways [8], the two major branches of defense-related signaling. On the whole, the coordination of defenses against biotrophic pathogens is mediated by SA, while the JA/ET tandem is associated with protection against necrotrophic pathogens, including Botrytis [41].

Our results, which are in line with previous studies, show that infection with $B$. cinerea in tomato and strawberry plants triggers the production of ET, JA and SA. Specifically, the increase in SA could be attributed to the activation of plant systemic acquired resistance (SAR) in response to $B$. cinerea infection, which promotes mechanisms that regulate defense systems against pathogens [90].

In recent years, there has been increasing interest in the development and use of bacteria capable of promoting plant ISR against various pathogens. Niu et al. (2011) [85] have documented the ability of B. cereus strain AR156 to activate ISR in Arabidopsis thaliana and consequently to accelerate the activation of cellular defense responses following infection with P. syringae pv tomato DC3000. Very similar results were obtained by Nie et al. (2017) [90] and Ahn et al. (2007) [83], who highlighted the fundamental role of the JA/ET-mediated signaling pathway in combating $B$. cinerea and P. syringae pv tomato. Elicitors synthesized by PGPR microorganisms capable of activating ISR include the lipopeptides surfactin, bacillomycin and phengicine, as well as the volatile organic compound 2,3-butanediol [21,28,35,79]. Foliar and radicular applications of strain XT1 on infected strawberry and tomato plants $(\mathrm{XT1}+\mathrm{Bc})$ modified phytohormone content considerably, with a high increase in JA levels. Given the ability of the biocontrol agent to reduce the infection caused by the phytopathogen and given the activation of the defense mechanisms detailed above, the increase in plant hormonal levels in non-infected and XT1-treated plants could be due to priming. Although our findings, with respect to phytohormone content in non-infected and infected XT1-treated plants, suggest that the JA/ET system is involved in the improvement of these defense systems, this fact needs to be confirmed through a more detailed analysis of signaling mechanisms triggered by the biological control agent XT1.

\section{Conclusions}

Greenhouse experiments on tomato and strawberry plants confirm that preventive applications of strain XT1 are capable of reducing the incidence and severity of $B$. cinerea-induced damage by over $50 \%$. In addition, our results show that treatment with strain XT1 improves plant growth and development in both infected and non-infected plants. The evaluation of the foliar and radicular modes of application suggests that the type of application used plays a fundamental role in the effectiveness of the biocontrol agent. According to our findings, while foliar applications of strain XT1 only led to high levels of antifungal activity, root applications of this biocontrol agent increased both plant biomass and protection against $B$. cinerea. Finally, the analysis of stress parameters and phytohormone content indicate that preventive applications of strain XT1 in plants following infection with $B$. cinerea promote the activation of defense mechanisms in strawberry and tomato plants. In addition, given the hormone levels observed, the signaling and activation pathways of these defense mechanisms could be mediated by the JA/ET pathway. Therefore, we could assume that the strain XT1 plays an important role in protecting against $B$. cinerea through the activation of induced systemic resistance (ISR) with the accumulation of callose deposits on cell walls and $\mathrm{H}_{2} \mathrm{O}_{2}$ production.

Author Contributions: L.T., I.S. and V.B. conceived and supervised the study and also designed the experiments; L.T. performed the experiments; M.R. performed the MDA experiments; L.T. and I.S. analyzed the data; L.T. prepared the figures and wrote the manuscript; L.T., I.S. and V.B. edited the manuscript and reviewed the literature. All authors have read and agreed to the published version of the manuscript.

Funding: The study was funded by Xtrem Biotech S.L (Granada, Spain), the Ramón y Cajal MINECO program (RYC-2014-15532) in Spain, the H2020 European Industrial Doctorates Project (UGR-Ref. 4726) and the Spanish Ministry of Economy (MINECO) Challenges-Collaboration Project (2015, RTC-2015-4121-2).

Acknowledgments: I.S. wishes to thank the Spanish Ministry of Economy (MINECO) for her Ramón y Cajal contract. Michael O'Shea corrected the manuscript. Assays were carried out in collaboration with Innoplant S.L. at the Estación Experimental del Zaidín (EEZ)—Spanish Research Council (CSIC) in Granada, Spain. 
Conflicts of Interest: The authors declare no conflicts of interest. The funders played no role in designing the study; collecting, analyzing or interpreting data; writing the manuscript or in the decision to publish the results.

\section{References}

1. Berg, G. Plant-microbe interactions promoting plant growth and health: Perspectives for controlled use of microorganisms in agriculture. Appl. Microbiol. Biotechnol. 2009, 84, 11-18. [CrossRef] [PubMed]

2. Chakraborty, S.; Newton, A.C. Climate change, plant diseases and food security: An overview. Plant Pathol. J. 2011, 60, 2-14. [CrossRef]

3. Gao, P.; Qin, J.; Li, D.; Zhou, S. Inhibitory effect and possible mechanism of a Pseudomonas strain QBA5 against gray mold on tomato leaves and fruits caused by Botrytis cinerea. PLoS ONE 2018, 13, e0190932. [CrossRef] [PubMed]

4. Dean, R.; Van Kan, J.A.; Pretorius, Z.A.; Hammond-Kosack, K.E.; Di Pietro, A.; Spanu, P.D.; Rudd, J.J.; Dickman, M.; Kahmann, R.; Ellis, J.; et al. The Top 10 fungal pathogens in molecular plant pathology. Mol. Plant Pathol. 2012, 13, 414-430. [CrossRef]

5. Nakajima, M.; Akutsu, K. Virulence factors of Botrytis cinerea. J. Gen. Plant Pathol. 2013, 80, 15-23. [CrossRef]

6. Finiti, I.; de la, O.; Leyva, M.; Vicedo, B.; Gomez-Pastor, R.; Lopez-Cruz, J.; Garcia-Agustin, P.; Real, M.D.; Gonzalez-Bosch, C. Hexanoic acid protects tomato plants against Botrytis cinerea by priming defence responses and reducing oxidative stress. Mol. Plant Pathol. 2014, 15, 550-562. [CrossRef]

7. Gonzalez-Fernandez, R.; Valero-Galvan, J.; Gomez-Galvez, F.J.; Jorrin-Novo, J.V. Unraveling the in vitro secretome of the phytopathogen Botrytis cinerea to understand the interaction with its hosts. Front. Plant Sci. 2015, 6, 839. [CrossRef]

8. El Oirdi, M.; El Rahman, T.A.; Rigano, L.; El Hadrami, A.; Rodriguez, M.C.; Daayf, F.; Vojnov, A.; Bouarab, K. Botrytis cinerea manipulates the antagonistic effects between immune pathways to promote disease development in tomato. Plant Cell 2011, 23, 2405-2421. [CrossRef]

9. Mengiste, T. Plant immunity to necrotrophs. Annu. Rev. Phytopathol. 2012, 50, 267-294. [CrossRef]

10. Sharma, E.; Kapoor, R. Insights into the molecular interplay of virulence factors in Botrytis cinerea. Australas. Plant Pathol. 2017, 46, 551-561. [CrossRef]

11. Fernandez-Ortuno, D.; Tores, J.A.; Chamorro, M.; Perez-Garcia, A.; de Vicente, A. Characterization of resistance to six chemical classes of site-specific fungicides registered for gray mold control on strawberry in Spain. Plant Dis. 2016, 100, 2234-2239. [CrossRef] [PubMed]

12. Luna, E.; Beardon, E.; Ravnskov, S.; Scholes, J.; Ton, J. Optimizing Chemically Induced resistance in tomato against Botrytis cinerea. Plant Dis. 2016, 100, 704-710. [CrossRef] [PubMed]

13. Salvatierra-Martinez, R.; Arancibia, W.; Araya, M.; Aguilera, S.; Olalde, V.; Bravo, J.; Stoll, A. Colonization ability as an indicator of enhanced biocontrol capacity-An example using two Bacillus amyloliquefaciens strains and Botrytis cinerea infection of tomatoes. J. Phytopathol. 2018, 166, 601-612. [CrossRef]

14. Pandin, C.; Le Coq, D.; Canette, A.; Aymerich, S.; Briandet, R. Should the biofilm mode of life be taken into consideration for microbial biocontrol agents? Microb. Biotechnol. 2017, 10, 719-734. [CrossRef] [PubMed]

15. Haas, D.; Défago, G. Biological control of soil-borne pathogens by fluorescent Pseudomonads. Nat. Rev. Microbiol. 2005, 3, 307-319. [CrossRef]

16. Beneduzi, A.A.; Ambrosini, A.; Passaglia, L.M.P. Plant growth-promoting rhizobacteria (PGPR): Their potential as antagonists and biocontrol agents. Genet. Mol. Biol. 2012, 35, 1044-1051. [CrossRef]

17. Pii, Y.; Mimmo, T.; Tomasi, N.; Terzano, R.; Cesco, S.; Crecchio, C. Microbial interactions in the rhizosphere: Beneficial influences of plant growth-promoting rhizobacteria on nutrient acquisition process. A review. Biol. Fertil. Soils 2015, 51, 403-415. [CrossRef]

18. Borriss, R. Use of Plant-associated Bacillus strains as biofertilizers and biocontrol agents in agriculture. In Bacteria in Agrobiology: Plant Growth Responses; Maheshwari, D.K., Ed.; Springer: Berlin/Heidelberg, Germany, 2011; pp. 41-76. [CrossRef]

19. Ruiz-Garcia, C.; Bejar, V.; Martinez-Checa, F.; Llamas, I.; Quesada, E. Bacillus velezensis sp. nov., a surfactant-producing bacterium isolated from the river Velez in Malaga, southern Spain. Int. J. Syst. Evol. Microbiol. 2005, 55, 191-195. [CrossRef] 
20. Fan, B.; Wang, C.; Song, X.F.; Ding, X.; Wu, L.; Wu, H.; Gao, X.; Borriss, R. Bacillus velezensis FZB42 in 2018 : The gram-positive model strain for plant growth promotion and biocontrol. Front. Microbiol. 2018, 9, 2491. [CrossRef]

21. Chowdhury, S.P.; Hartmann, A.; Gao, X.; Borriss, R. Biocontrol mechanism by root-associated Bacillus amyloliquefaciens FZB42-A review. Front. Microbiol. 2015, 6, 780. [CrossRef]

22. Frikha-Gargouri, O.; Ben Abdallah, D.; Ghorbel, I.; Charfeddine, I.; Jlaiel, L.; Triki, M.A.; Tounsi, S. Lipopeptides from a novel Bacillus methylotrophicus 39b strain suppress Agrobacterium crown gall tumours on tomato plants. Pest Manag. Sci. 2017, 73, 568-574. [CrossRef]

23. Jemil, N.; Manresa, A.; Rabanal, F.; Ben Ayed, H.; Hmidet, N.; Nasri, M. Structural characterization and identification of cyclic lipopeptides produced by Bacillus methylotrophicus DCS1 strain. J. Chromatogr. A 2017, 1060, 374-386. [CrossRef] [PubMed]

24. Ongena, M.; Jacques, P. Bacillus lipopeptides: Versatile weapons for plant disease biocontrol. Trends Microbiol. 2008, 16, 115-125. [CrossRef] [PubMed]

25. Asari, S.; Matzen, S.; Petersen, M.A.; Bejai, S.; Meijer, J. Multiple effects of Bacillus amyloliquefaciens volatile compounds: Plant growth promotion and growth inhibition of phytopathogens. FEMS Microbiol. Ecol. 2016, 92, fiw070. [CrossRef] [PubMed]

26. Lim, S.M.; Yoon, M.Y.; Choi, G.J.; Choi, Y.H.; Jang, K.S.; Shin, T.S.; Park, H.W.; Yu, N.H.; Kim, Y.H.; Kim, J.C. Diffusible and volatile antifungal compounds produced by an antagonistic Bacillus velezensis G341 against various phytopathogenic fungi. Plant Pathol. J. 2017, 33, 488-498. [CrossRef]

27. Perez-Flores, P.; Valencia-Cantero, E.; Altamirano-Hernandez, J.; Pelagio-Flores, R.; Lopez-Bucio, J.; Garcia-Juarez, P.; Macias-Rodriguez, L. Bacillus methylotrophicus M4-96 isolated from maize (Zea mays) rhizoplane increases growth and auxin content in Arabidopsis thaliana via emission of volatiles. Protoplasma 2017, 254, 2201-2213. [CrossRef]

28. Myo, E.M.; Liu, B.; Ma, J.; Shi, L.; Jiang, M.; Zhang, K.; Ge, B. Evaluation of Bacillus velezensis NKG-2 for bio-control activities against fungal diseases and potential plant growth promotion. Biol. Control 2019, 134, 23-31. [CrossRef]

29. Fan, B.; Blom, J.; Klenk, H.P.; Borriss, R. Bacillus amyloliquefaciens, Bacillus velezensis, and Bacillus siamensis form an "operational group B. amyloliquefaciens" within the B. subtilis species complex. Front. Microbiol. 2017, 8, 22. [CrossRef]

30. Van Loon, L.; Bakker, P.; Pieterse, C. Systemic resistance induced by rhizosphere bacteria. Annu. Rev. Phytopathol. 1998, 36, 453-483. [CrossRef]

31. Conrath, U.; Beckers, G.; Flors, V.; García-Agustín, P.; Jakab, G.; Mauch, F.; Newman, M.-A.; Pieterse, C.; Poinssot, B.; Pozo, M.; et al. Priming: Getting ready for battle. Mol. Plant-Microbe Interact. MPMI 2006, 19, 1062-1071. [CrossRef]

32. Cawoy, H.; Mariutto, M.; Henry, G.; Fisher, C.; Vasilyeva, N.; Thonart, P.; Dommes, J.; Ongena, M. Plant defense stimulation by natural isolates of Bacillus depends on efficient surfactin production. Mol. Plant-Microbe Interact. 2014, 27, 87-100. [CrossRef] [PubMed]

33. Pertot, I.; Puopolo, G.; Hosni, T.; Pedrotti, L.; Jourdan, E.; Ongena, M. Limited impact of abiotic stress on surfactin production in planta and on disease resistance induced by Bacillus amyloliquefaciens $\mathrm{S} 499$ in tomato and bean. FEMS Microbiol. Ecol. 2013, 86, 505-519. [CrossRef] [PubMed]

34. Luna, E.; Pastor, V.; Robert, J.; Flors, V.; Mauch-Mani, B.; Ton, J. Callose deposition: A multifaceted plant defense response. Mol. Plant-Microbe Interact. 2011, 24, 183-193. [CrossRef]

35. Rahman, A.; Uddin, W.; Wenner, N.G. Induced systemic resistance responses in perennial ryegrass against Magnaporthe oryzae elicited by semi-purified surfactin lipopeptides and live cells of Bacillus amyloliquefaciens. Mol. Plant. Pathol. 2015, 16, 546-558. [CrossRef]

36. Pastor, V.; Luna, E.; Ton, J.; Cerezo, M.; García-Agustín, P.; Flors, V. Fine tuning of reactive oxygen species homeostasis regulates primed immune responses in Arabidopsis. Mol. Plant-Microbe Interact. 2013, 26, 1334-1344. [CrossRef] [PubMed]

37. Gonzalez-Bosch, C. Priming plant resistance by activation of redox-sensitive genes. Free Radic. Biol. Med. 2018, 122, 171-180. [CrossRef]

38. Pieterse, C.M.; Leon-Reyes, A.; Van der Ent, S.; Van Wees, S.C. Networking by small-molecule hormones in plant immunity. Nat. Chem. Biol. 2009, 5, 308-316. [CrossRef] 
39. Blanco-Ulate, B.; Vincenti, E.; Powell, A.L.; Cantu, D. Tomato transcriptome and mutant analyses suggest a role for plant stress hormones in the interaction between fruit and Botrytis cinerea. Front. Plant Sci. 2013, 4, 142. [CrossRef]

40. Martinez-Hidalgo, P.; Garcia, J.M.; Pozo, M.J. Induced systemic resistance against Botrytis cinerea by Micromonospora strains isolated from root nodules. Front. Microbiol. 2015, 6, 922. [CrossRef]

41. Bari, R.; Jones, J.D. Role of plant hormones in plant defence responses. Plant. Mol. Biol. 2009, 69, 473-488. [CrossRef]

42. López-Escudero, F.; Del Río, C.; Caballero, J.; Blanco-López, M. Evaluation of olive cultivars for resistance to Verticillium dahliae. Eur. J. Plant Pathol. 2004, 110, 79-85. [CrossRef]

43. Mukherjee, S.; Choudhuri, M. Implications of water stress-induced changes in the levels of endogenous ascorbic acid and hydrogen peroxide in Vigna seedlings. Physiol. Plant. 1983, 58, 166-170. [CrossRef]

44. Heath, R.L.; Packer, L. Photoperoxidation in isolated chloroplasts: I. Kinetics and stoichiometry of fatty acid peroxidation. Arch. Biochem. Biophys. 1968, 125, 189-198. [CrossRef]

45. Scalschi, L.; Sanmartín, M.; Camañes, G.; Troncho, P.; Sánchez-Serrano, J.J.; García-Agustín, P.; Vicedo, B. Silencing of OPR3 in tomato reveals the role of OPDA in callose deposition during the activation of defense responses against Botrytis cinerea. Plant J. 2015, 81, 304-315. [CrossRef]

46. Stevens, G.A.; Berry, A.M. Cytokinin secretion by Frankia sp. HFP ArI3 in defined medium. Plant Physiol. 1988, 87, 15-16. [CrossRef]

47. Villaverde, J.J.; Sevilla-Moran, B.; Sandin-Espana, P.; Lopez-Goti, C.; Alonso-Prados, J.L. Biopesticides in the framework of the European Pesticide Regulation (EC) No. 1107/2009. Pest Manag. Sci. 2014, 70, 2-5. [CrossRef] [PubMed]

48. Lamichhane, J.R.; Dachbrodt-Saaydeh, S.; Kudsk, P.; Messean, A. Toward a reduced reliance on conventional pesticides in european agriculture. Plant Dis. 2016, 100, 10-24. [CrossRef] [PubMed]

49. Perez-Garcia, A.; Romero, D.; de Vicente, A. Plant protection and growth stimulation by microorganisms: Biotechnological applications of Bacilli in agriculture. Curr. Opin. Biotechnol. 2011, 22, 187-193. [CrossRef]

50. Romanazzi, G.; Lichter, A.; Gabler, F.M.; Smilanick, J.L. Recent advances on the use of natural and safe alternatives to conventional methods to control postharvest gray mold of table grapes. Postharvest Biol. Techonl. 2012, 63, 141-147. [CrossRef]

51. Béjar, V.; Llamas, I.; Ruíz-García, C.; Quesada, E. Uso de Bacillus methylotrophicus Como Estimulante del Crecimiento Vegetal y Medio de Control Biológico, y Cepas Aisladas de Dicha Especie. U.S. Patent No. 20170215429, 3 August 2017.

52. Berrada, I.; Benkhemmar, O.; Swings, J.; Bendaou, N.; Amar, M. Selection of halophilic bacteria for biological control of tomato gray mould caused by Botrytis cinerea. Phytopathol. Mediterr. 2012, 51, 625-630. [CrossRef]

53. Sylla, J.; Alsanius, B.W.; Krüger, E.; Wohanka, W. Control of Botrytis cinerea in strawberries by biological control agents applied as single or combined treatments. Eur. J. Plant Pathol. 2015, 143, 461-471. [CrossRef]

54. Marín, A.; Cháfer, M.; Atarés, L.; Chiralt, A.; Torres, R.; Usall, J.; Teixidó, N. Effect of different coating-forming agents on the efficacy of the biocontrol agent Candida sake CPA-1 for control of Botrytis cinerea on grapes. Biol. Control 2016, 96, 108-119. [CrossRef]

55. Lugtenberg, B.; Kamilova, F. Plant-growth-promoting rhizobacteria. Annu. Rev. Microbiol. 2009, 63, 541-556. [CrossRef] [PubMed]

56. Erturk, Y.; Ercisli, S.; Cakmakci, R. Yield and Growth Response of strawberry to plant growth-promoting rhizobacteria inoculation. J. Plant Nutr. 2012, 35, 817-826. [CrossRef]

57. Myresiotis, C.K.; Karaoglanidis, G.S.; Vryzas, Z.; Papadopoulou-Mourkidou, E. Evaluation of plant-growth-promoting rhizobacteria, acibenzolar-S-methyl and hymexazol for integrated control of Fusarium crown and root rot on tomato. Pest Manag. Sci. 2012, 68, 404-411. [CrossRef]

58. Meng, Q.; Jiang, H.; Hao, J.J. Effects of Bacillus velezensis strain BAC03 in promoting plant growth. Biol. Control 2016, 98, 18-26. [CrossRef]

59. Zhao, D.; Zhao, H.; Zhao, D.; Zhu, X.; Wang, Y.; Duan, Y.; Xuan, Y.; Chen, L. Isolation and identification of bacteria from rhizosphere soil and their effect on plant growth promotion and root-knot nematode disease. Biol. Control 2018, 119, 12-19. [CrossRef]

60. Madhaiyan, M.; Poonguzhali, S.; Kwon, S.W.; Sa, T. Bacillus methylotrophicus sp. nov., a methanol utilizing, plant-growth-promoting bacterium isolated from rice rhizosphere soil. Int. J. Syst. Evol. Microbiol. 2010, 60, 2490-2495. [CrossRef] 
61. Torres, M.; Llamas, I.; Torres, B.; Toral, L.; Sampedro, I.; Béjar, V. Growth promotion on horticultural crops and antifungal activity of Bacillus velezensis XT1. Appl. Soil Ecol. 2020, 150, 103453. [CrossRef]

62. Palencia, P.; Martínez, F.; Pestana, M.; Oliveira, J.A.; Correia, P.J. Effect of Bacillus velezensis and Glomus intraradices on fruit quality and growth parameters in strawberry soil-less growing system. Hortic. J. 2015, 84, 122-130. [CrossRef]

63. Esitken, A.; Yildiz, H.E.; Ercisli, S.; Figen Donmez, M.; Turan, M.; Gunes, A. Effects of plant growth promoting bacteria (PGPB) on yield, growth and nutrient contents of organically grown strawberry. Sci. Hortic. 2010, 124, 62-66. [CrossRef]

64. Grady, E.N.; MacDonald, J.; Ho, M.T.; Weselowski, B.; McDowell, T.; Solomon, O.; Renaud, J.; Yuan, Z.C. Characterization and complete genome analysis of the surfactin-producing, plant-protecting bacterium Bacillus velezensis 9D-6. BMC Microbiol. 2019, 19, 5. [CrossRef] [PubMed]

65. Luo, W.; Liu, L.; Qi, G.; Yang, F.; Shi, X.; Zhao, X. Embedding Bacillus velezensis NH-1 in microcapsules for biocontrol of cucumber Fusarium wilt. Appl. Environ. Microbiol. 2019, 85, e03128-18. [CrossRef] [PubMed]

66. Pandin, C.; Darsonval, M.; Mayeur, C.; Le Coq, D.; Aymerich, S.; Briandet, R. Biofilm formation and synthesis of antimicrobial compounds by the biocontrol agent Bacillus velezensis QST713 in an Agaricus bisporus compost micromodel. Appl. Environ. Microbiol. 2019, 85, e00327-19. [CrossRef]

67. Toral, L.; Rodríguez, M.; Béjar, V.; Sampedro, I. Antifungal activity of lipopeptides from Bacillus XT1 CECT 8661 against Botrytis cinerea. Front. Microbiol. 2018, 9, 1315. [CrossRef]

68. Azabou, M.C.; Gharbi, Y.; Medhioub, I.; Ennouri, K.; Barham, H.; Tounsi, S.; Triki, M.A. The endophytic strain Bacillus velezensis OEE1: An efficient biocontrol agent against Verticillium wilt of olive and a potential plant growth promoting bacteria. Biol. Control 2020, 142, 104168. [CrossRef]

69. Wang, S.; Sun, L.; Zhang, W.; Chi, F.; Hao, X.; Bian, J.; Li, Y. Bacillus velezensis BM21, a potential and efficient biocontrol agent in control of corn stalk rot caused by Fusarium graminearum. Egypt. J. Biol. Pest Control 2020, 30, 9. [CrossRef]

70. Dhouib, H.; Zouari, I.; Abdallah, D.B.; Belbahri, L.; Taktak, W.; Triki, M.A.; Tounsi, S. Potential of a novel endophytic Bacillus velezensis in tomato growth promotion and protection against Verticillium wilt disease. Biol. Control 2019, 139, 104092. [CrossRef]

71. Chen, L.; Wu, Y.D.; Chong, X.Y.; Xin, Q.H.; Wang, D.X.; Bian, K. Seed-borne endophytic Bacillus velezensis LHSB1 mediate the biocontrol of peanut stem rot caused by Sclerotium rolfsii. J. Appl. Microbiol. 2020, 128, 803-813. [CrossRef]

72. Trinh, T.H.T.; Wang, S.L.; Tran, M.D.; Doan, C.T.; Vo, T.P.K.; Huynh, Q.V.; Nguyen, A.D. A potent antifungal rhizobacteria Bacillus velezensis RB. DS29 isolated from black pepper (Piper nigrum L.). Res. Chem. Intermed. 2019, 45, 5309-5323. [CrossRef]

73. Liu, Y.; Teng, K.; Wang, T.; Dong, E.; Zhang, M.; Tao, Y.; Zhong, J. Antimicrobial Bacillus velezensis HC6: Production of three kinds of lipopeptides and biocontrol potential in maize. J. Appl. Microbiol. 2020, 128, 242-254. [CrossRef] [PubMed]

74. Jiang, C.H.; Liao, M.J.; Wang, H.K.; Zheng, M.Z.; Xu, J.J.; Guo, J.H. Bacillus velezensis, a potential and efficient biocontrol agent in control of pepper gray mold caused by Botrytis cinerea. Biol. Control 2018, 126, 147-157. [CrossRef]

75. Lee, J.P.; Lee, S.-W.; Kim, C.S.; Son, J.H.; Song, J.H.; Lee, K.Y.; Kim, H.J.; Jung, S.J.; Moon, B.J. Evaluation of formulations of Bacillus licheniformis for the biological control of tomato gray mold caused by Botrytis cinerea. Biol. Control 2006, 37, 329-337. [CrossRef]

76. Ilhan, K.; Karabulut, O.A. Efficacy and population monitoring of bacterial antagonists for gray mold (Botrytis cinerea Pers. ex. Fr.) infecting strawberries. BioControl 2013, 58, 457-470. [CrossRef]

77. Shternshis, M.V.; Belyaev, A.A.; Shpatova, T.V.; Lelyak, A.A. Influence of Bacillus spp. on strawberry gray-mold causing agent and host plant resistance to disease. Contemp. Probl. Ecol. 2015, 8, 390-396. [CrossRef]

78. Fan, B.; Chen, X.H.; Budiharjo, A.; Bleiss, W.; Vater, J.; Borriss, R. Efficient colonization of plant roots by the plant growth promoting bacterium Bacillus amyloliquefaciens FZB42, engineered to express green fluorescent protein. J. Biotechnol. 2011, 151, 303-311. [CrossRef] [PubMed]

79. Al-Ali, A.; Deravel, J.; Krier, F.; Bechet, M.; Ongena, M.; Jacques, P. Biofilm formation is determinant in tomato rhizosphere colonization by Bacillus velezensis FZB42. Environ. Sci. Pollut. Res. 2018, 25, 29910-29920. [CrossRef] [PubMed] 
80. Mihalache, G.; Balaes, T.; Gostin, I.; Stefan, M.; Coutte, F.; Krier, F. Lipopeptides produced by Bacillus subtilis as new biocontrol products against fusariosis in ornamental plants. Environ. Sci. Pollut. Res. 2018, 25, 29784-29793. [CrossRef]

81. Wu, Y.; Zhou, J.; Li, C.; Ma, Y. Antifungal and plant growth promotion activity of volatile organic compounds produced by Bacillus amyloliquefaciens. MicrobiologyOpen 2019, 8, e00813. [CrossRef] [PubMed]

82. Conrath, U.; Pieterse, C.M.; Mauch-Mani, B. Priming in plant-pathogen interactions. Trends Plant Sci. 2002, 7, 210-216. [CrossRef]

83. Ahn, I.-P.; Lee, S.-W.; Suh, S.-C. Rhizobacteria-induced priming in Arabidopsis is dependent on ethylene, jasmonic acid, and NPR1. Mol. Plant-Microbe Interact. 2007, 20, 759-768. [CrossRef]

84. Asselbergh, B.; Curvers, K.; Franca, S.C.; Audenaert, K.; Vuylsteke, M.; Van Breusegem, F.; Hofte, M. Resistance to Botrytis cinerea in sitiens, an abscisic acid-deficient tomato mutant, involves timely production of hydrogen peroxide and cell wall modifications in the epidermis. Plant Physiol. 2007, 144, 1863-1877. [CrossRef]

85. Niu, D.-D.; Liu, H.-X.; Jiang, C.-H.; Wang, Y.-P.; Wang, Q.-Y.; Jin, H.-L.; Guo, J.-H. The plant growth-promoting rhizobacterium Bacillus cereus AR156 induces systemic resistance in Arabidopsis thaliana by simultaneously activating salicylate-and jasmonate/ethylene-dependent signaling pathways. Mol. Plant-Microbe Interact. 2011, 24, 533-542. [CrossRef]

86. Lopez-Cruz, J.; Crespo-Salvador, O.; Fernández-Crespo, E.; García-Agustín, P.; González-Bosch, C. Absence of $\mathrm{Cu}-\mathrm{Zn}$ superoxide dismutase BCSOD1 reduces Botrytis cinerea virulence in Arabidopsis and tomato plants, revealing interplay among reactive oxygen species, callose and signalling pathways. Mol. Plant Pathol. 2017, 18, 16-31. [CrossRef]

87. Meng, L.; Höfte, M.; Van Labeke, M.-C. Leaf age and light quality influence the basal resistance against Botrytis cinerea in strawberry leaves. Environ. Exp. Bot. 2019, 157, 35-45. [CrossRef]

88. Tomas-Grau, R.H.; Requena-Serra, F.J.; Hael-Conrad, V.; Martinez-Zamora, M.G.; Guerrero-Molina, M.F.; Diaz-Ricci, J.C. Soft mechanical stimulation induces a defense response against Botrytis cinerea in strawberry. Plant Cell Rep. 2018, 37, 239-250. [CrossRef]

89. Silva, H.S.A.; da Silva Romeiro, R.; Macagnan, D.; de Almeida Halfeld-Vieira, B.; Pereira, M.C.B.; Mounteer, A. Rhizobacterial induction of systemic resistance in tomato plants: Non-specific protection and increase in enzyme activities. Biol. Control 2004, 29, 288-295. [CrossRef]

90. Nie, P.; Li, X.; Wang, S.; Guo, J.; Zhao, H.; Niu, D. Induced systemic resistance against Botrytis cinerea by Bacillus cereus AR156 through a JA/ET- and NPR1-dependent signaling pathway and activates PAMP-triggered immunity in Arabidopsis. Front. Plant Sci. 2017, 8, 238. [CrossRef] [PubMed]

91. García-Cristobal, J.; García-Villaraco, A.; Ramos, B.; Gutierrez-Manero, J.; Lucas, J.A. Priming of pathogenesis related-proteins and enzymes related to oxidative stress by plant growth promoting rhizobacteria on rice plants upon abiotic and biotic stress challenge. J. Plant Physiol. 2015, 188, 72-79. [CrossRef]

92. Lian, Q.; Zhang, J.; Gan, L.; Ma, Q.; Zong, Z.; Wang, Y. The Biocontrol efficacy of Streptomyces pratensis LMM15 on Botrytis cinerea in tomato. BioMed Res. Int. 2017, 2017, 1-11. [CrossRef] [PubMed]

93. Khanna, K.; Jamwal, V.L.; Kohli, S.K.; Gandhi, S.G.; Ohri, P.; Bhardwaj, R.; Abd Allah, E.F.; Hashem, A.; Ahmad, P. Plant growth promoting rhizobacteria induced Cd tolerance in Lycopersicon esculentum through altered antioxidative defense expression. Chemosphere 2019, 217, 463-474. [CrossRef] [PubMed]

94. Erdogan, Ü.; Çakmakçi, R.; Varmazyari, A.; Turan, M.; Erdogan, Y.; Kitir, N. Role of inoculation with multi-trait rhizobacteria on strawberries under water deficit stress. Zemdirbyste 2016, 103, 67-76. [CrossRef]

(C) 2020 by the authors. Licensee MDPI, Basel, Switzerland. This article is an open access article distributed under the terms and conditions of the Creative Commons Attribution (CC BY) license (http://creativecommons.org/licenses/by/4.0/). 